\title{
PERILAKU PERAWAT DALAM UPAYA PENERAPAN KESEHATAN DAN KESELAMATAN KERJA DI RUMAH SAKIT
}

\author{
Friderikus Zebua \\ zebuafriderikus@gmail.com
}

\section{LATAR BELAKANG}

Kesehatan dan Keselamatan Kerja (K3) merupakan salah satu isu penting di dunia kerja saat ini termasuk di lingkungan rumah sakit. Angka kecelakaan kerja di rumah sakit lebih tinggi dibandingkan tempat kerja lainnya dan sebagian besar diakibatkan oleh perilaku yang tidak aman. Perawat adalah tenaga kesehatan yang paling besar jumlahnya dan paling lama kontak dengan pasien, sehingga sangat berisiko dengan pekerjaannya, namun banyak perawat tidak menyadari terhadap risiko yang mengancam dirinya, melupakan keselamatan dan kesehatan kerja (K3). K3 adalah upaya yang bertujuan untuk meningkatkan dan memelihara derajat kesehatan fisik, mental dan sosial yang setinggi-tingginya bagi pekerja di semua jenis pekerjaan, pencegahan terhadap gangguan kesehatan pekerja yang disebabkan oleh kondisi pekerjaan; perlindungan bagi pekerja dalam pekerjaannya dari risiko akibat faktor yang merugikan kesehatan. Adapun tujuan dari penulisan ini adalah untuk mengetahui apa itu K3RS, apa tujuan dari K3RS dan bagaimana peran perawat dalam penerapan K3 di rumah sakit. Metode penulisan ini adalah Literature Riview, dimana ini menganalisis artikel yang relevan dan berfokus pada tema yaitu upaya perawat dalam menerapkan K3 di rumah sakit.

Perilaku manusia merupakan unsur yang memegang peranan penting dalam mengakibatkan suatu kecelakaan, sehingga cara yang efektif untuk mencegah terjadinya kecelakaan kerja adalah dengan menghindari terjadinya perilaku tidak aman. Dari hasil studi pendahuluan di RS Islam Asshobirin 7 dari 10 perawat yang diamati berperilaku aman dengan memakai APD saat bekerja sedangkan sisanya tidak berperilaku aman. Penelitian ini bertujuan untuk mengetahui dan menggali secara mendalam bagaimana perilaku aman dan faktor penyebab perbedaan perilaku pada perawat sebagai salah satu tenaga kesehatan di rumah sakit dalam mencegah terjadinya kecelakaan. 
Berdasarkan data dari World Health Organization (WHO) : Dari 35 juta pekerja kesehatan 3 juta terpajan patogen darah (2 juta terpajan virus HBV, 0,9 juta terpajan virus HBC dan 170,000 terpajan virus HIV/ AIDS). Dapat terjadi : 15,000 HBC, 70,000 HBB \& 1000 kasus HIV. Lebih dari $90 \%$ terjadi di negara berkembang.8-12\% pekerja rumah sakit,sensitif terhadap lateks. Probabilitas penularan HIV setelah luka tusuk jarum suntik yang terkontaminasi HIV 4: 1000. Risiko penularan HBV setelah luka tusuk jarum suntik yang terkontaminasi HBV 27-37: 100. Risiko penularan HCV setelah luka tusuk jarum suntik yang mengandung HCV 3 - 10 : 100 (Sunandar, 2017)

\section{METODE}

Metode yang digunakan pada kajian ini adalah metode kualitatif yang memberikan penjelasan dengan menggunakan analisis pada referensi-refensi yang berupa jurnal dan artikel yang sudah di publikasikan. Artikel ataupun jurnal yang digunakan pada literature ini adalah artikel atau jurnal yang didapatkam dari google scholar, google, library usu pada 10 tahun terakhir penerbitan. Dalam mencari literature reviewnya, menggunakan kata kunci berpikir kritis, pengambilan keputusan keperawatan dan perawat.

\section{HASIL}

Berdasarkan pencarian literature didapatkan apa defenisi K3RS, tujuan dari K3RS dan juga didapatkan informasi tentang peran perawat dalam penerapan K3 di Rumah Sakit. Semua faktor yang dapat menentukan atau membentuk perilaku manusia disebut determinan perilaku. Determinan perilaku manusia terdiri dari faktor internal dan faktor eksternal. Faktor internal yaitu karakteristik dari individu yang bersangkutan yang bersifat bawaan sedangkan faktor eksternal yaitu faktor yang berasal dari luar diri seseorang.

\section{PEMBAHASAN}

Peran perawat pada berbagai ruang lingkup K3RS secara keseluruhan dirasa penting untuk diterapkan. Tanpa disadari bahwa, penerapan K3RS perawat di Rumah Sakit dapat mempengaruhi kualitas perawat, kenyamanan pasien, maupun juga citra Rumah Sakit. Melalui komunikasi terapeutik perawat sudah dapat menerapkan K3RS kepada pasien yang dapat mempengaruhi kenyamanan pasien. Seperti misalnya, pada pasien yang akan menjalani proses pembedahan. Menurut Siswoyo \& Roymond (2009), menyatakan bahwa pasien yang akan menjalani proses pembedahan akan mengalami kecemasan bahkan akan berakibat pada kualitas kenyamanan pasien yang akan mempengaruhi pasien lainnya.

Kecemasan tersebut terjadi karena pemikiran pasien yang memiliki persepsi bahwa tindakan pembedahan akan memperburuk kualitas hidupnya. Maka dirasa perlu dilakukan nya komunikasi oleh perawat demi kenyamanan pasien di Rumah Sakit. Semua faktor yang dapat 
menentukan atau membentuk perilaku manusia disebut determinan perilaku. Determinan perilaku manusia terdiri dari faktor internal dan faktor eksternal. Faktor internal yaitu karakteristik dari individu yang bersangkutan yang bersifat bawaan sedangkan faktor eksternal yaitu faktor yang berasal dari luar diri seseorang (Notoatmodjo, 2010).Persepsi merupakan suatu proses pencarian informasi yang dilakukan oleh perawat sebelum melakukan suatu tindakan.

Persepsi perawat tentang K3 menunjukkan bagaimana perawat mampu mencari tahu tentang pentingnya K3 baik melalui brosur, leaflet, SOP yangdisediakan di ruangan maupun media informasi lainnya. Perawat juga dituntut untuk faham bagaimana cara pencegahan kecelakaan serta penanganan yang dapat dilakukan apabila kecelakaan terjadi. Pemahaman tersebut akan menimbulkan persepsi yang baik dalam diri perawat tentang K3 sehingga hal ini akanmeningkatkan perilakunya dalam menjaga keselamatan. Selain persepsi, sikap juga mempengaruhi perilaku perawat ditinjau dari segi faktor internal (Notoadmodjo, 2010).Seorang perawat.dalam melaksanakan manajemen K3 harus memiliki sikap yang sesuai dengan nilai-nilai kesehatan dimana seluruh nilai positif yang ada dalam dirinya menjadi pendorong perilaku sehat dan menjadi upaya dalam meningkatkan kesehatan dan keselamatan selama bekerja. Selain itu, Notoadmodjo (2010) menambahkan bahwa ada berbagai cara yang dapat dilakukan untuk meningkatkan persepsi, pengetahuan dan sikap perawat dalam menjaga kesehatan dan keselamatan selama bekerja, diantaranya dengan memberikan promosi kesehatan dan pelatihan tentang K3sehingga hal ini diharapkan mampu merubah perilaku perawat menjadi lebih baik.

Selain faktor internal, faktor eksternal juga sangat mempengaruhi perilaku perawat dalam penerapan manajemen K3 di rumah sakit. Peneliti berasumsi bahwa ada banyak faktor yang dapat menentukan perubahan perilaku perawat dari segi faktor eksternal, diantaranya pengalaman. Pengalaman perawat dapat dilihat dari berbagai aspek. Salah satunya adalah masa kerja. Semakin lama masa kerja perawat maka pengalaman yang dimiliki juga semakin meningkat sehingga perilakunya dalam menjaga keselamatan dirinya juga menjadi lebih baik. Selain itu pengalaman juga dapat diperoleh dari berbagai sosialisasi maupun pelatihan tentang $\mathrm{K} 3$ yang dilakukan oleh pihak rumah sakit

Rumah sakit merupakan sarana pelayanan yang bergerak dibidang pelayanan jasa kesehatan yang mempunyai beragam persoalan tenaga kerja yang rumit dengan berbagai risiko terkena penyakit akibat kerja bahkan kecelakaan akibat kerja sesuai jenis pekerjaannya sehingga berkewajiban menerapkan upaya pembinaan Keselamatan dan Kesehatan Kerja Rumah Sakit (K3RS). Upaya ini dijalankan agar terhidar dari adanya risiko kecelakaan kerja (Astono, 2010). Kecelakaan kerja merupakan kejadian yang tidak terjadi secara kebetulan, melainkan ada sebabnya. Menurut WHO pengertian K3 adalah upaya yang bertujuan untuk meningkatkan dan memelihara derajat kesehatan fisik mental dan sosial yang setinggi tingginya bagi pekerja di semua jenis pekerjaan, pencegahan terhadap .gangguan kesehatan pekerja yang disebabkan oleh kondisi pekerjaan;perlindungan bagi pekerja dalam pekerjaannya dari risiko akibat faktor yang merugikan kesehatan. Tujuan umum dari K3 adalah menciptakan tenaga kerja yang sehat dan produktif. Tujuan hyperkes dapat dirinci sebagai berikut (Rachman, 1990) : 
a. Agar tenaga kerja dan setiap orang berada di tempat kerja selalu dalam keadaan sehat dan selamat.

b. Agar sumber-sumber produksi dapat berjalan secara lancar tanpa adanya hambatan.

Keselamatan pasien (patient safety) adalah permasalahan yang sangat penting dalam setiap pelayanankesehatan sehingga keselamatan merupakan tanggung jawab dari pemberi jasa pelayanan kesehatan terutama pelayanan keperawatan di setiap unit perawatan baik akut maupun kronis harus berfokus pada keselamatan pasien baik dalam tatanan rumah sakit. Penerapan keselamatan pasien ini dapat terlaksana dalam setiap tugas dan tanggung jawab yang akan dilakukan oleh perawat. Perawat dituntut untuk bertanggung jawab dalam setiap tindakannya khususnya selama melaksanakan tugas baik di rumah sakit, puskesmas, panti, klinik atau masyarakat.

Meskipun tidak dalam angka tugas atau tidak sedang melaksanakan dinas, perawat dituntut bertanggung jawab dalam tugas-tugas yang melekat dalam diri perawat. Perawat memiliki peran dan fungsi yang sudah disepakati. Tanggung jawab perawat erat kaitannya dengan tugas tugas perawat. Tugas perawat secara umum adalah memenuhi kebutuhan dasar serta mengutamakan dan mengoptimalkan keselamatan pasien.Terdapat beberapa faktor yang mempengaruhi kepatuhan perawat dalam melaksanakan K3RS diantaranya yaitu : Pengalaman, pengalaman perawat dapat dilihat dari berbagai aspek. Salah satunya adalah masa kerja. Semakin lama masa kerja perawat maka pengalaman yang dimiliki juga semakin meningkat sehingga perilakunya dalam menjaga keselamatan dirinya juga menjadi lebih baik. Selain itu pengalaman juga dapat diperoleh dari berbagai sosialisasi maupun pelatihan tentang K3 yang dilakukan oleh pihak rumah sakit. Faktor selanjutnya yang ikut berperan dalam perubahan perilaku perawat yaitu tersedianya fasilitas yang mendukung sesuai dengan standar yang telah ditentukan.

Faktor enabling (fasilitas keamanan dan keselamatan, hukum/aturan) pada perawat berpengaruh terhadap K3 pada perawat dalam penanganan pasien. Nilai yang paling tinggi pada faktor enabling berada pada komponen hukum/aturan, artinya secara umum perilaku seseorang dipengaruhi oleh aturan yang ada di lingkungannya. Selain beberapa faktor diatas, budaya organisasi juga berpengaruh terhadap perilaku perawat dalam melaksanakan keselamatan, dimana budaya organisasi yang baik akan mendorong perawat untuk bekerja sesuai dengan prosedur yang telah ditetentukan (Notoadmodjo, 2010) Perawat sangatlah berperan penting dalam meningkatan kesehatan dan keselamatan kerja di Rumah sakit maka Perawat sebaiknya terus mengembangkan pengetahuan dan keterampilan di bidang manajemen keperawatan khususnya terkait Kesehatan dan Keselamatan Kerja (K3) sehingga pelayanan yang diberikan dapat lebih optimal dan berkualitas tanpa melupakan tingkat kesehatan dan keselamatan bagi pemberi asuhan keperawatan. 


\section{PENUTUP}

Cara yang dapat dilakukan untuk meningkatkan persepsi, pengetahuan dan sikap perawat dalam menjaga kesehatan dan keselamatan selama bekerja, diantaranya dengan memberikan promosi kesehatan dan pelatihan tentang $\mathrm{K} 3$ sehingga hal ini diharapkan mampu merubah perilaku perawat menjadi lebihbaik.

Menurut WHO pengertian K3 adalah upaya yang bertujuan untuk meningkatkan dan memelihara derajat kesehatan fisik, mental dan sosial yang setinggi-tingginya bagi pekerja di semua jenis pekerjaan, pencegahan terhadap gangguan kesehatan pekerja yang disebabkan oleh kondisi pekerjaan; perlindungan bagi pekerja dalam pekerjaannya dari risiko akibat faktor yang merugikan kesehatan.Tanggung jawab perawat erat kaitannya dengan tugas tugas perawat. Tugas perawat secara umum adalah memenuhi kebutuhan dasar serta mengutamakan dan mengoptimalkan keselamatan pasien

Rumah Sakittelah menerapkan kebijakan sistem manajemen keselamatan dan kesehatan kerja rumah sakit (SMK3 RS), dimana Rumah Sakit Mitra Sejati Medan telah membuat kebijakan K3RS berupa surat keputusan yang ditetapkan oleh direktur rumah sakit dan dibuat secara resmi dan tertulis.Proses perencanaan K3RS di RS Mitra Sejati Medan telah mengacu pada kebijakan pelaksanaan keselamatan dan kesehatan kerja, dimana perencanaan program yang dilaksanakan sudah ada ditetapkan dan memiliki pedoman dalam penanggulangan keselamatan dan kesehatan kerja di rumah sakit.Pelaksanaan keselamatan dan kesehatan kerjarumah sakit disini telah disusun berdasarkan rencana tetapi hanya beberapa rencana yang telah dijalankan sesuai dengan peraturan yang telah ditetapkan.

\section{DAFTAR PUSTAKA}

Azrul, A. (1996). Menuju Pelayanan Kesehatan Yang Bermutu. Jakarta : Salemba Medika. Departemen Kesehatan RI. (2008). Upaya Peningkatan Mutu Pelayanan Rumah Sakit. Jakarta: Depkes RI.

Efendi, Ferry, dan Makhfudli. (2009). Keperawatan Kesehatan Komunitas :Teori dan Praktik Dalam Keperawatan. Jakarta : Salemba Medika.

Ferry,Efendi dan Makhfudli.2009.Teori dan Praktik dalam Keperawatan.Jakarta: Salemba Medika

Firawati. (2012). Pelaksanaan Program Keselamatan Pasien di RSUD Solok.Jurnal Kesehatan Masyarakat, Vol 6, No 2.Harus, B. D.(2015). Pengetahuan Perawat Tentang Keselamatan Pasien dengan Pelaksanaan Prosedur Keselamatan Pasien Rumah Sakit (KPRS) di Rumah Sakit Panti Waluyu Sawahan Malang. Jurnal CARE, Vol 3, No1. 
Hidayat, A. Aziz Alimul. (2008). Pengantar Konsep Dasar Keperawatan.Jakarta: Salemba Medika.

Harus, B. D.(2015). Pengetahuan Perawat Tentang Keselamatan Pasien dengan Pelaksanaan Prosedur Keselamatan Pasien Rumah Sakit (KPRS) di Rumah Sakit Panti Waluyu Sawahan Malang. Jurnal CARE, Vol 3, No1.

Ismainar, Hetty. (2015). Keselamatan Pasien di Rumah Sakit. Yogyakarta: Deepublish. Kusnanto. (2004). Pengantar Profesi \& Praktik Keperawatan Profesional.Jakarta : EGC.

Nursalam. (2002). Manajemen Keperawatan : Aplikasi Dalam Praktik Keperawatan Profesional. Jakarta :EGC

Simamora, R. H. (2018). Buku ajar keselamatan pasien melalui timbang terima pasien berbasis komunikasi efektif: SBAR. Medan: USUpress.

Simamora, R. H. (2019). Buku ajar pelaksanaan identifikasi pasien. Uwais Inspirasi Indonesia.

Ulumiyah, N. H. (2018). Meningkatkan Mutu Pelayanan Kesehatan dengan Penerapan Upaya Keselamatan Pasien di Puskesmas. Jurnal Administrasi Kesehatan Indonesia, Vol 6(2) : $149-155$

Utarini, A, Djasri, H. (2012).Keselamatan pasien dan Mutu Pelayanan kesehatan. Jurnal Manajemen Pelayanan Kesehatan. 159-160. 